\title{
Pesticide Pollution, Resistance and Health Hazards
}

\author{
M. Ahmed Azmi and S.N.H. Naqvi \\ Baqai Medical University \\ Pakistan
}

\section{Introduction}

The origin and concept, known exactly, of pesticides is not known. Pesticides or insecticides (insect killers) are among the most extensively used chemicals in the world today and they are also among the most hazardous compounds to the human being as well. Though, some pesticides can be beneficial in decreasing the populations of harmful or destructive insects, while others can be damaging to the environment and can cause serious disturbances. In this connection, studies have shown that pesticides can be extremely unsafe, particularly when they run off into water ways or if used indiscriminately can cause both short term and long term damage to the people and the environment. Humans can also be adversely affected by pesticides and this can cause many people to change their life style according to the situation. Synthetic pesticides are behind many people's decision to switch to organic products and practices, especially where diet is concerned. The number of people demanding pesticide - free organic food has increased sharply in recent years as more information has been uncovered about the health risks associated with pesticides. Additionally, some pesticides have a resistance to breaking down over time, which means that their effects can continue over a long period of time.

All pesticides may be effective against the pests, when they are used for control. They must be biologically active or toxic. As pesticides are toxic by nature, they are also potentially hazardous to human, animals, other organisms as well as the environment. Therefore, people who use pesticides or regularly come in contact with them must understand the relative toxicity and preventive measures to reduce exposure to the products they use. A report from World Health Organization (WHO) indicated that over 200,000 people are killed due to the toxicity of these dangerous chemicals every year. The casualty figure in fact do not confirm the real picture of poisoning caused by the frequent use of pesticides but about over three million of poisoning cases have been reported annually. Exposure to these pesticides or hazardous chemicals therefore leads to several health problems such as asthma attacks, skin rashes as well as chronic disorders like emphysema and cancer. Therefore, what steps or needs to be done immediately is to reduce the adverse health effects caused by the pesticides and if they are found to be dangerous beyond a maximum level, restrictions should be imposed on their use as well as exposure to human health. Some organochlorine pesticides have been banned in this connection. (e.g. DDT, dieldirin, endrin etc.). 


\section{Important}

It is important to note that pesticides and pollution are linked together. Pesticides are a cause of pollution affecting land and water in particular. Water pollution is one of the leading cause of death. At present, only a small portion of waste water is treated. The rest is discharged into our water bodies. Due to this pollutants enter in ground water, rivers and other water bodies. Such water which ultimately ends up in our households is often highly contaminated and produces diseases. Agricultural run off or the water from the fields that drains into rivers is another major pollutant as it contains pesticides and fertilizers. Pesticides when used properly are of tremendous benefits to human beings but their indiscriminate use however may cause considerable hazards to health and environment. Pointing out the effects of pesticides on human body, there is a wide range of health problem caused by the continuous exposure of pesticides like still births, neonatal deaths, congenital birth defects, paralysis, depressed respiration, cardiovascular dysfunctions, cancer and tumor etc. Problems with the use of pesticides are usually worse in developing countries where many products of the WHO category I are still in use. As these products are highly toxic in nature (WHO, 1962), their continuous exposure ultimately result in poisoning.

Keeping the environmental and health problem in priority, there is a strong public pressure to reduce their use as they are costly and causing various problems e.g., pesticide pollution, resistance in pests and accumulation of residues of pesticides in the body of animals and human beings.

On this basis, the developed countries are preferring the use of phytopesticides and hormonal pesticides under IPM program to avoid any risk to human health. In this chapter, discussion is focused on the environmental impact of pesticide exposure particularly in relation to pollution, resistance and hazardous effects on human health. Through this work, we strongly recommend suggestions to the pesticide users and regulatory bodies in providing extensive awareness programs for the safe use of pesticides before spraying and handling. Furthermore, effective health monitoring policy should be taken into consideration with in the community for minimizing human exposure to pesticides.

\section{Information}

\section{Pesticides}

Any substance or mixture of substances intended for preventing, destroying, repelling or mitigating any insects, rodents, nematodes, fungi or weeds or any other forms of life declared to be pests are called pesticides. Pests are those organisms which harm us and our belongings. Pesticides are used globally and extensively for the control of pests. Plant growth regulators, which are used to influence particular growth process in plants, are also regulated as pesticides.

\section{Classification of pesticides}

a. Pesticides is a general term which may be classified according to the pests e.g.,

- Insecticides which kill or destroy insects

- Acaricides which kill ticksand mites cause seabiasis (Acarines)

- Rodenticides which kill rodents (Rats etc)

- Fungicides which kill fungi

- Algaecides which kill algae 
- Weedicides which kill weeds

- Bactericides which kill bacteria

- Molluscicides which control slugs or snails

- Nematicides which control nematodes

- Virucides which control viruses

b. Pesticides can also be grouped on the basis synthetic organic chemical compounds.

i. Chlorirated hydrocarbons $(O C)$ :

They include DDT, BHC (Lindane), Heptachlor, Aldrin, Dieldrin, Endrin etc. In addition PCB's are also hydrocarbons but not used as insecticides. This group came in general use in 1940. It is persistent and have long half life (i.e. 15-30 years). Some of them are very toxic e.g. endrin ( $\left.\mathrm{LD}_{50} 10-15 \mathrm{mg} / \mathrm{kg}\right)$.

ii. Chlorophenoxy acids $(2,4-D)$ :

They are being used since 1930 as herbicides and include 2, 4, dichlorophenoxy acetic acid. They are toxic for plants especially broad leaf plants or weeds and mimic plant hormones. They are less toxic to animals but may produce eye inritation and GIT disorder. They are degraded in about two weeks but regular exposure may be teratogenic in animals.

iii. Organo-phosphates $(O P)$ :

Organo-phosphates came in general use as pesticides in 1950 as a result of the development of resistance against OC, DDT etc. They are more toxic to mammals but they are degraded in 2-4 weeks. The common insecticides are malathion (comparatively more safe for mammals), parathion, methyl parathion, dimecron, diazinon, dimethoate, chlorpyriphos, DDVP or dichlorovos, TTEP etc. They are compound of phosphorus and sulphur. Basically, they are acetylcholine esterase inhibitors. Among them TEPP is the most toxic i.e. $\mathrm{LD}_{50} 1 \mathrm{mg} / \mathrm{kg}$ while malathion is least toxic i.e. $\mathrm{LD}_{50} 1500 \mathrm{mg} / \mathrm{kg}$.

In Pakistan they were being frequently used (50\%) for plant protection till 1991. Some of the components of this series are used as nerve gases for military purpose e.g. Agents GB They have shorter half life and quickly degrade, but their first metabolite is more toxic e.g. paraoxon, malaoxon.

iv. Carbamates $(C B)$ :

They are esters of carbonic acid and first developed in Nigeria by U.K. scientists. They include propoxur (baygon), carbaryl (sevin), Temik and Zectran. They are also less peristant and degrade in about 4 weeks. They are also acetylcholinesterase inhibitors. Some are less toxic while some are more toxic e.g. propoxur $\mathrm{LD}_{50} 30 \mathrm{mg} / \mathrm{kg}$.

v. Synthetic pyrethroids $(S P)$ :

They are being mostly used these days because they are less toxic for mammals but sufficiently toxic for insects. They also inhibit cholinesterase. They have been developed on the basis of natural pyrethroids (pyrethrins I-IV) found in chrysanthemum flower. The natural pyrethrins have immediate knockdown effect but are less toxic and less persistant. The synthetic pyrethroids have more toxic and persistant effect. The examples of these are permethnin, bioallethrin, resmethrin, cypermetrhin etc. Synthetic pyrethroids also have a half life of $2-4$ weeks. They are also general esterase inhibitors and have effects on other enzymes as well.

Different groups of pesticides remained popular in different periods. In early days inorganic and plant extracts were popular, but in 40's 50's organochlorine (OC) became popular especially DDT was reported as "Wonder drug" during $2^{\text {nd }}$ World War. For this great work 
of achievement Muller was awarded a noble prize. In 60's and 70's Organophosphates (OP) and Carbamates (CB) became popular and OP are still being used. However, in 80's synthetic pyrethroids (SP) dominated the sense and still the maximum import and use of pyrethroids is being done by government and private sectors because pyrethroids are comparatively safer and more effective as well. It is belived that in the next century, plant products will dominate due to their safe use and less polluting effect. Moreover, they also remain active physiologically by nature.

At present following pesticides are in major use:

Cypermethrin, Permethrin, Bioallithrin, Fenvalerate, Methamidophos, Monocrotophos, Sumithion, Dimethoate, Endosulphan, Triazophos, Acephate etc.

\section{Mode of Action}

Pesticides are basically poisons and therefore toxic to living organism at particular dose. They are inhibitors of enzymes and disturb the normal biochemical reactions necessary for metabolism. Some of them are neurotoxins while others are cytotoxins. They affect the action of enzymes in the body. However, the body has the ability to degrade and detoxify them by the help of various enzymes for example:

a. Organochlorines:

Organochlorines (OC) are degraded by dehydrochlorinases.

b. Organophosphates:

Organophosphates (OP) are degraded by general esterases such as cholinesterases (ChEase), Phosphomonoesterases (ACP, AKP), Carboxylesterases and Oxidases.

c. Carbamates:

d. Carbamates (CB) and synthetic pyrethroids (SP) are also degraded by the above enzymes. Most of them are cholinesterase inhibitors that disturb the nerve transmission system. However, the body has the power to synthesize more enzymes and degrade these poisons by increasing the enzyme levels such as the development of resistance in case of pests.

\section{A. Pesticide Pollution:}

Although pesticides are intended to harm only the target pest, if not used correctly, they can also harm to the people or the environment. Pesticide intoxication may be caused either by swallowing accidently, or by inhalation of fumes or by skin contact or accidental eye exposure.

In case of eye exposure through washing, it is necessary to wash the eyes with running water for at least 15 minutes. If there is still burning effect use eye drops or rose water several times. In severe cases consult eye specialist and a toxicologist.

In case of skin contact, immediately remove the clothing and wash the effected clothings in washing machines separetly, If there is still some effect consult skin specialist and toxicologist.

In case of Inhalation take the patient to open and uncontaminated area. During difficulty in breathing, use proper respiratory equipment and if there is severe difficulty in breathing use oxygen. Do not leave unconscious person unattended. Consult a physician and toxicologist for proper guidance.

In case of swallowing, immediately induce vomiting. (never induce vomiting to an unconscious person). After vomiting advice the patient to take milk, butter and egg, so that pesticide may bind with them and excreted. Consult a physician and toxicologist for advice. 
Some pesticides evaporate more easily and quickly than others so these pesticides are more likely to be inhaled. Some pesticides degrade more quickly on surfaces where as others last longer. Therefore, the more a person is exposed to a particular pesticide or substance the greater is the risk or chance of harm. So, the degree of harm depends on the chemical nature of chemical compounds, the situation of environment and the person life style. This means that very small amounts of pesticides or even the most toxic material may either cause nothing or can cause little harm to the person. On the other hand less toxic materials taken in large amount can cause greater harm.

\section{Assessment of human exposure with pesticides}

Basically pesticides are potentially dangerous and harmful to human and other living organisms. They not only pollute the environment but also produce pathological effects in various organs. In human beings, the pesticide residual level is an index of exposure. Presence of different pesticide residual level in the blood of human being clearly indicate that up to which extent or degree to which the person is exposed and this has been done through high performance liquid chromatographic (HPLC) technique and gas chromatography (GC) to quantify the level of pesticide residues in their blood using chromatogram. The incidence of exposure to pesticides may either be acute, occupational or incidental. In general population the residual level is a measure of the incidental exposure and the levels of persistent pesticides remain in the soil and tissues for year together and their bioaccumulation takes place via food chain. Unfortunately, the body has the ability to biotransformation and excretes part of these compounds in urine, fecal matter, bile and air. However when the rate of absorption and deposition in fat exceeds to the rate of elimination, their higher concentration results in toxic and pathological effects.

In view of this, in the developed countries EPA keeps a constant watch on the pesticidal pollution by regular check up and do not hesitate in destroying the large food stocks. Extensive literature in these countries are available on this issue (Heath 1961; Cohen and Oostarbaan 1963; O'Brien 1967, 1976; Casarette et al. 1968; Krauthacker et al. 1980; Mercedes and Theil 1986; Anna et al. 1988; Alawi et al. 1992; Cantor et al. 1992; Ferrer et al. 1992; Matuo et al. 1993; Saddy et al. 1993; Swaen et al. 1994). However, in Pakistan little work has been done by Mughal and Rehman 1973; Naqvi and Jahan, 1996. Some work has also been done by Pakistan Agriculture Research Center (PARC) but mostly on crops. Therefore there is urgent need of investigating pesticide residues in human blood and their pathological effects.

\section{Pesticide Residues}

Pesticide residues are very small amounts of pesticides that can remain in the blood, tissues or on a crop for years and their bioaccumulation takes place via food chain. Not all foods contain pesticide residues and whenever they occur they are found typically at low levels. Pesticide residues also include any breakdown products from the pesticides.

\section{Pesticide residues in human blood}

Studies have been done extensively all over the world pertaining to the presence of pesticides in human biological material. In this connection several reports have been published by Krauthacker et al. 1980; Saxena et al. 1980; Mercedes and Thiel 1986; Sabbah et al. 1987; Krawinkel et al. 1989; Greve and Zoonen 1990; Chikuni et al. 1991; and Kanja et al. 1992. However, this type of information in Pakistan is scanty and the only report available 
in early 70's is that of Mughal and Rahman (1973), Therefore, a study was conducted by Naqvi and Jahan, (1995) in which thirty random samples of blood were taken for pesticide determination from three different laboratories of Karachi. Almost all the samples reported here were found contaminated with organochlorine $(\mathrm{OC})$ compounds. However, samples obtained from two centres were found to have more pesticides. Workers deputed to chlorination plants (i.e., third centre) have greater quantity of tenakil and other OC compounds. Among all the samples analyzed, only a few were found to have deltamethrin (pyrethroids) and malathion (organophosphate) possibly because of fresh exposure. The detail has been given in tables 1, 2 and 3 for information.

\begin{tabular}{|c|c|c|c|c|c|c|}
\hline Samples & DDT & DDE & Dieldrin & Aldrin & Deltamethrin & Malathion \\
\hline 1. & - & - & 0.033 & - & - & - \\
2. & - & 0.022 & - & - & - & 2.0 \\
3. & - & 0.423 & - & - & - & - \\
4. & - & - & 0.02 & - & - & 2.0 \\
5. & - & 0.004 & - & - & - & $30.0^{*}$ \\
6. & - & - & - & - & - & 4.0 \\
7. & - & 0.008 & - & $18.0^{*}$ & - & - \\
8. & 0.006 & 0.008 & - & - & - & - \\
9. & - & 0.008 & - & - & - & 0.2 \\
10. & - & - & 0.035 & - & - & - \\
\hline
\end{tabular}

Table 1. Contents of pesticides $(\mu \mathrm{g} / \mathrm{ml})$ in sera samples obtained from Aziz Laboratory, Karachi. (*Above maximum residue limit).

In this centre, samples of blood were taken from persons whose age varied from 6 to 36 years. Only two pesticides viz., malathion $(30.0 \mu \mathrm{g} / \mathrm{ml})$ and Aldrin $(18.0 \mu \mathrm{g} / \mathrm{ml})$ were found in highest concentration. Sample 9 of this centre indicates the presence of one OC and one OP compound. However, sample 10 showed a very peculiar case. This sample was obtained from a girl who was only 6 years old but the serum sample had $0.035 \mu \mathrm{g} / \mathrm{ml}$ of DDE. It is possible that she received this parent compound of DDE i.e., DDT through her mother which then degraded to DDE. This is in accordance with the reports of Chikuni et al. (1991) and Kanja et al. (1992). Therefore, it is clear from the data summarized in these tables

\begin{tabular}{|c|c|c|c|c|c|}
\hline \multirow{2}{*}{ Samples } & DDT & DDE & \multicolumn{2}{|c|}{ Aldrin } & P2 \\
\hline 1. & 0.026 & 0.57 & 36.0 & 0.131 & \multirow{2}{*}{ Deltamethrin } \\
2. & 0.063 & 0.627 & $24.7^{*}$ & $0.019^{*}$ & $12.22^{*}$ \\
3. & - & 0.640 & - & - & 3.40 \\
4. & - & 0.373 & $10.0^{*}$ & 0.057 & - \\
5. & - & 0.113 & - & - & 2.23 \\
6. & - & 0.069 & - & - & - \\
7. & 0.004 & 0.069 & - & - & - \\
8. & 0.009 & - & - & - & - \\
9. & 0.008 & - & - & - & - \\
10. & - & - & - & - & 1.03 \\
\hline
\end{tabular}

Table 2. Content of pesticides ( $\mu \mathrm{g} / \mathrm{ml}$ ) in sera samples from Fatimid Foundation (*Above maximum residue limit). 


\begin{tabular}{|c|c|c|c|c|}
\hline Samples & DDT & DDE & Dieldrin & Tenakil \\
\hline 1. & - & - & 0.09 & 1.336 \\
2. & - & - & 0.23 & $4.456^{*}$ \\
3. & 0.005 & 0.028 & - & $7.278^{*}$ \\
4. & - & - & 0.09 & 1.336 \\
5. & - & - & 0.23 & 1.336 \\
6. & - & - & 0.27 & 1.188 \\
7. & - & - & 0.08 & $7.278^{*}$ \\
8. & - & - & 0.51 & 13.369 \\
9. & 0.004 & - & 0.51 & $43.673^{*}$ \\
10. & - & - & $5.73^{*}$ & $11.580^{*}$ \\
\hline
\end{tabular}

Table 3. Contents of pesticides $(\mu \mathrm{g} / \mathrm{ml}$ ) in sera samples from chlorination plant of PCSIR (*Blood sample taken with in an hour after exposure to tenakil).

that dieldrin and DDE were the main pollutants in all the anaylyzed samples (Table 2 and Table 3). However, tenakil and dieldrin were indentified in higher amounts in persons at the chlorimation plant and Aziz laboratory.

The same type of study was also conducted by Azmi and Naqvi (2005) in which blood samples were collected from the persons (especially farm workers and spray man) engaged in different fruit and vegetable farm stations located at Gadap (rural area) Karachi Pakistan. Total 287 blood samples were taken from exposed and control persons and 81 samples were taken for residual analysis by HPLC and 55 samples were found positive. Analysis of all the samples by HPLC revealed the presence of Polytrin - C only in one sample, while deltamethrin and diazinon were detected in 4 and 7 samples, respectively. However, the frequently detected pesticides were cypermethrin, monocrotophos and DDE (one of the metabolite of DDT). Therefore, it is concluded that $29.6 \%$ cases of organophosphates, $29.6 \%$ cases of organochlorines and $48.1 \%$ cases of pyrethriods were detected.

We are presenting here the data related to the pesticide residues only of such persons from Gadap (rural area) of Karachi and different regions of Sindh province of Pakistan who are highly exposed with one or more pesticides. The total number of samples (city wise in asterisk superscript) analyzed from each centre and the highest / lowest value are given in the Table 4 (as the data is quite extensive) for information.

Thus, the data presented regarding the detection of pesticide residues in the blood samples of the farm workers and general population belonging to different cities of Sindh divisions of Pakistan clearly indicate that the persons engaged in the field work have greater quantity of pesticides such as cypermethrin, deltamethrin profenofos, diazinon, monocrotphos, DDT, DDE and permethrin because of greater exposure of these pesticides during spraying time in these areas. In this connection highest quantity of pesticides such as $12.22 \mathrm{mg} / \mathrm{ml}$ by Jahan (1995) and Bissacot and Vassilieff (1997-b) was reported in case of deltamethrin; 100 $200 \mathrm{mg} / \mathrm{ml}$ by Abu-Qare and Abu-Donia (2001-a), 80 - $200 \mathrm{mg} / \mathrm{ml}$ by Abu-Qare and AbuDonia (2001-b); slightly high value $0.025-5.0 \mu \mathrm{g} / \mathrm{ml}$ by Musshoff et al. (2002) in case of diazinon. In case of monocrotophos; slightly high level $0.025-50 \mathrm{mg} / \mathrm{g}$ by Musshoff et al. (2002) $0.27 \mathrm{mg} / \mathrm{ml}$ by Kocan et al. (1994), $0.9 \mathrm{mg} / \mathrm{L}$ by Guardino et al. (1996), $4.71 \mathrm{mg} /$ $\mathrm{L}$ and $38.13 \mathrm{mg} / \mathrm{L}$ by Dua et al. (1996), $1.9 \mathrm{ppb}$ by Luo et al. (1997), $0.78 \mathrm{mg} / \mathrm{kg}$ by Waliszewski et al. (2000) was reported in the blood samples. Low level of DDT $0.22 \mathrm{mg} / \mathrm{L}$, $0.25 \mathrm{mg} / \mathrm{L}$ and $0.30 \mathrm{mg} / \mathrm{L}$ was also reported by Heudorf et al. (2003). In case of DDE, high 


\begin{tabular}{|c|c|c|c|c|c|c|c|c|c|c|}
\hline \multirow{3}{*}{ City } & \multicolumn{10}{|c|}{ Pesticide Residues $(\mu \mathrm{g} / \mathrm{ml})$} \\
\hline & \multirow{2}{*}{ Cyper } & \multirow{2}{*}{ Delta } & \multicolumn{2}{|c|}{ Polytrin-C } & \multirow{2}{*}{ Dia } & \multirow{2}{*}{ Mono } & \multirow{2}{*}{ DDT } & \multirow{2}{*}{ DDE } & \multirow{2}{*}{ Mal } & \multirow{2}{*}{ Perm } \\
\hline & & & Cyper & Prof & & & & & & \\
\hline $\begin{array}{l}\text { Gadap } 81 \\
\text { Karachi }\end{array}$ & $\begin{array}{c}31^{*} \\
\uparrow 32.40\end{array}$ & $\begin{array}{c}4^{*} \\
\uparrow 40.00\end{array}$ & - & $\begin{array}{c}1^{*} \\
\uparrow 65.50\end{array}$ & $\begin{array}{c}9^{*} \\
\uparrow 28.80 \\
\end{array}$ & $\begin{array}{c}16^{*} \\
\uparrow 43.50\end{array}$ & $\begin{array}{c}12^{*} \\
\uparrow 21.60\end{array}$ & $\begin{array}{c}13^{*} \\
\uparrow 42.50\end{array}$ & - & - \\
\hline Thatta 17 & $\begin{array}{c}4^{*} \\
\uparrow 10.53\end{array}$ & $\begin{array}{c}5^{*} \\
\uparrow 5.49\end{array}$ & - & - & - & - & $\begin{array}{c}1^{*} \\
\uparrow 2.45\end{array}$ & $\begin{array}{c}1^{*} \\
\uparrow 1.71\end{array}$ & - & $\begin{array}{c}1^{*} \\
\uparrow 3.58\end{array}$ \\
\hline Hyderabad 7 & $\begin{array}{c}2^{*} \\
\uparrow 5.61\end{array}$ & $\begin{array}{c}2^{*} \\
\uparrow 11.12\end{array}$ & - & $\uparrow 16.51$ & - & - & - & - & - & $\begin{array}{c}2^{*} \\
\uparrow 8.82\end{array}$ \\
\hline Rohri $^{3}$ & - & - & - & - & - & - & - & - & - & $\begin{array}{c}1^{*} \\
\uparrow 6.66 \\
\end{array}$ \\
\hline Shadadpur ${ }^{3}$ & - & $\begin{array}{c}1^{*} \\
\uparrow 3.52\end{array}$ & - & - & - & - & - & - & - & - \\
\hline Tando M. Khan ${ }^{3}$ & $\begin{array}{c}1^{*} \\
\uparrow 9.36\end{array}$ & - & - & - & - & - & - & - & - & - \\
\hline Sukkur ${ }^{4}$ & - & $\begin{array}{c}1^{*} \\
\uparrow 4.39\end{array}$ & - & - & - & - & - & - & - & $\begin{array}{c}1^{*} \\
\uparrow 24.05\end{array}$ \\
\hline Dadu $^{4}$ & $\begin{array}{c}1^{*} \\
\downarrow 2.65\end{array}$ & - & - & - & - & - & - & $\begin{array}{c}1^{*} \\
\downarrow 1.10\end{array}$ & - & - \\
\hline Nawab Shah ${ }^{2}$ & - & - & - & - & - & - & - & - & - & $\begin{array}{c}1^{*} \\
\uparrow 3.94 \\
\end{array}$ \\
\hline Larkana $^{3}$ & - & $\begin{array}{c}2^{*} \\
\uparrow 22.42 \\
\downarrow 0.34\end{array}$ & - & $\begin{array}{c}1^{*} \\
\uparrow 30.76\end{array}$ & - & - & - & - & - & $\begin{array}{c}2^{*} \\
\uparrow 6.15 \\
\uparrow 4.01\end{array}$ \\
\hline Sanghar ${ }^{4}$ & $\begin{array}{c}1^{*} \\
\uparrow 11.17 \\
\end{array}$ & $\begin{array}{c}1^{*} \\
\uparrow 3.98 \\
\end{array}$ & - & - & - & - & - & $\begin{array}{c}1^{*} \\
\uparrow 3.06\end{array}$ & - & - \\
\hline
\end{tabular}

Superscript number in cities $=$ Total No. of Samples, Cyper $=$ Cypermethrin, Delta $=$ Deltamethrin ${ }^{*}$ number $=$ Number of detection of pesticides, Prof $=$ Profenofos, Mala $=$ Malathion, Perm $=$ Permethrin, Dia $=$ Diazinon, Mono $=$ Monoerotophos, $\uparrow=$ Highest value, $\downarrow=$ Low value, $-=$ Not detecrted.

Table 4. Quantitative analysis of pesticide residues in the blood of effected persons from different arm stations of Gadap (rural area).

quantity $8.0 \mathrm{mg} / \mathrm{L}$ by Guardina et al. (1996), $9.10 \mathrm{mg} / \mathrm{ml}$ by Rubin et al. (2001) and $380 \mathrm{mg} / \mathrm{kg}$ by Ntow et al. (2001) was reported in the exposed persons. Residues of DDE were also detected such as 5.2,6.2 and $2.5 \mathrm{ng} / \mathrm{g}$ by Ahmed et al. (2002), $3.99 \mathrm{mg} / \mathrm{ml}$ and $1.42 \mathrm{mg} / \mathrm{ml}$ by Butler et al. (2003). High level of DDE was also reported by Van Ooastdam et al. (2004).

\section{Pesticide residues in glandular tissue}

Thyroid gland tissues were tested for the presence of pesticides ( i.e., DDT, DDE, aldrin, dieldrin, malathion and deltamethrin). This study was based on the glandular tissue samples that were collected from Jinnah Postgraduate Medical Centre (JPMC) during surgical operations. The data collected from this centre for the detection of pesticide residue is summarized as below: 


\begin{tabular}{|c|c|c|c|c|c|c|}
\hline \multirow{2}{*}{$\begin{array}{c}\text { Sample } \\
(\mathbf{2 0})\end{array}$} & \multicolumn{7}{|c|}{ Pesticide residues ( $\boldsymbol{g g} / \mathbf{g m})$} \\
\cline { 2 - 6 } & DDT & DDE & Dieldrin & Aldrin & Malathion & Deltamethrin \\
\hline I & 0.011 & - & - & - & - & - \\
II & 0.044 & - & - & 20.0 & - & - \\
\hline
\end{tabular}

Table 5. Content of pesticide residues in glandular tissue samples from Jinnah Hospital, Karachi-Pakistan.

The table indicates the presence of DDT and Aldrin only in two positive samples out of total 20 samples. The amount of DDT detected in both samples is much less than MPL (Maximum Residual Limit). However, the amount of Aldrin is more than MRL which seems to be dangerous for the health point of view because the organochlorine pesticides are lipophilic. If thyroid gland can accumulate this much quantity of aldrin, then large quantity of this pesticide might have been deposited in the fatty tissues of that patient. In case of prolonged illness the fatty tissue may release lethal dose of aldrin ( $\mathrm{LD}_{50}$ for mammals is $10 \mathrm{mg} / \mathrm{kg}$ ). So, there is a probable risk for this patient. Moreover effect of pesticides on hormones and endocrine glands (adrenal cortex) have been reported by Vilar and Tullner (1959); Kuservitsky et al. (1970) on thyroid gland and by De Sola et al. (1998); Jarrer et al. (1998); You et al. (1998) and Padungtod et al. (1998) on hormones. Effect of dieldrin (Cyclodiene) has been reported by Wakeling et al. (1972) on 5-dihydrotestosterone binding with specific protein receptors, as 33\% inhibition. This indicates that pesticides affect the hormones and endocrine glands.

\section{Pesticide residues in fruits and vegetables}

Pesticide residues were also detected in fruits and vegetables samples collected from Karachi markets. Only 45 commodities were tested (out of 145 samples) for residual analysis. The data obtained are given as under:

\begin{tabular}{|c|c|c|c|}
\hline \multicolumn{2}{|c|}{ Karachi Fruit Market } & \multicolumn{2}{c|}{ Karachi Vegetable Market } \\
\hline Fruits & Pesticides & Vegetables & Pesticides \\
\hline Mango Peel & $\begin{array}{c}\text { Heptachlos } \\
\mathrm{P}^{\prime} \mathrm{P}^{\prime} \mathrm{DDT}\end{array}$ & Cauliflower & $\begin{array}{c}\text { Alpha-BHC } \\
\text { Aldrin }\end{array}$ \\
\hline Peach Peel & Heptachlor & Potato & $\begin{array}{c}\text { gamma-BHC } \\
\text { Heptachlor }\end{array}$ \\
\hline Pear & $\mathrm{P}^{\prime} \mathrm{P}^{\prime} \mathrm{DDT}$ & Lady Fingers & Heptachlor Aldrin \\
\hline Banana Peel & Beta-BHC & Cucumber & Heptachlor \\
\hline Orange Peel & Alpha-BHC & Turnip & gamma-BHC \\
\hline Blackberry & $\begin{array}{c}\text { gamma-BHC } \\
\text { Heptachlor }\end{array}$ & Lady Fingers & gamma-BHC Aldrin \\
\hline
\end{tabular}

Table 6. Organochlorine pesticide residues in fruits and vegetables of Karachi market.

The table indicates that mostly the fruits and vegetables contain organochlorine pesticide residues such as Heptachlor, BHC and DDT which is quite dangerous and alarming for the health of general people as these food items are the basic need of human being. It is therefore, suggested that the fuits and vegetables used by human should be washed thoroughly for any hazardous incident. 


\section{Pesticide residues in tissues, fresh water lakes and fishes}

Data on pesticide residues related to fresh water lakes of Sindh and the fishes present in these lakes as well as different tissues are representing in tables.

\begin{tabular}{|c|c|c|c|c|c|}
\hline \multirow{2}{*}{ Sample } & \multicolumn{5}{|c|}{ Pesticide residues $(\boldsymbol{\mu g} / \mathbf{g})$} \\
\cline { 2 - 6 } & Dimethoate & DDT & DDE & Cypermethrin & Dieldrin \\
\hline Water & ND & ND & ND & ND & ND \\
\hline Fat & $4.06 \pm 0.67$ & $2.38 \pm 0.26$ & $1.54 \pm 0.19$ & $0.2 \pm 0.01$ & $0.12 \pm 0.12$ \\
\hline Muscles & $0.12 \pm 0.66$ & $0.68 \pm 0.29$ & $0.56 \pm 0.26$ & ND & ND \\
\hline Liver & $0.01 \pm 0.01$ & $0.28 \pm 0.17$ & $0.56 \pm 0.19$ & ND & ND \\
\hline
\end{tabular}

Table 7. Content of pesticide residues in lake water, fat, muscles and liver samples from Egretta sp. found in Kalri lake. (ND = Not detected).

\begin{tabular}{|c|c|c|c|c|c|}
\hline \multirow{2}{*}{ Sample } & \multicolumn{5}{|c|}{ Pesticide residues $(\mu \mathrm{g} / \mathrm{g})$} \\
\cline { 2 - 6 } & Dimethoate & DDT & DDE & Cypermethrin & Dieldrin \\
\hline Water & $2.2 \pm 0.18$ & $2.8 \pm 0.65$ & $4.4 \pm 0.76^{* *}$ & $2.1 \pm 0.17$ & $0.05 \pm 0.03$ \\
\hline \multirow{2}{*}{ Fat } & $17.44 \pm 1.49^{* *}$ & $\begin{array}{c}7.62 \pm \\
0.48^{*}\end{array}$ & $\begin{array}{c}73.3 \pm \\
0.16^{* * *}\end{array}$ & $7.08 \pm 0.16^{*}$ & $6.92 \pm 0.59^{*}$ \\
\hline \multirow{2}{*}{ Muscles } & $11.48 \pm 1.92^{* *}$ & $\begin{array}{c}5.56 \pm \\
0.81^{*}\end{array}$ & $\begin{array}{c}31.88 \pm \\
3.63^{* * *}\end{array}$ & $5.34 \pm 0.38^{*}$ & $1.24 \pm 0.08$ \\
\hline \multirow{2}{*}{ Liver } & $2.28 \pm 0.51$ & $2.7 \pm 0.51$ & $\begin{array}{c}6.86 \pm \\
0.36^{*}\end{array}$ & $5.52 \pm 0.24^{*}$ & $0.41 \pm 0.09$ \\
\hline
\end{tabular}

Table 8. Content of pesticide residues in lake water, fat, muscles and liver samples from Egretta sp., found in Haleji lake. (ND = Not detected)

The present data indicates that in the birds of Kalri lake only the fat samples contain dimethoate to some extent. This may be due to the constant use of this pesticide by the farmers and that too by bioaccumulation. The water samples however from this lake had no pesticide in detectable quantity. In Haleji lake, the water samples had DDE in slightly high quantity. However, the birds had high level of dimethoate, very high level of DDE and slightly high level of DDT, cypermethrin and dieldrin. Although, use of DDT has been banned long ago, but is very persistent and metabolized slowly this is evident from the very high level of its metabolite DDE. In muscles also the high level of DDE was found which supports the findings found in fat samples. In case of muscles, DDT and cypermethrin was found in slightly high quantity. This means that birds bioaccumulate pesticides in fats and muscles which is dangerous for human beings, as they reach via food chain.

\section{Residues in Adipose tissues}

By the present report it may be conluded that adipose tissues of Karachi people have OC, $\mathrm{OP}$ and pyrethroid insecticide residues. As far as their concentration is concerned, the higher concentration was of pyrethroid group i.e., deltamethrin. Adipose tissues had no OP compound instead they had OC pesticides among which dieldrin and DDT are dominating. Aldrin was found in higher concentration, possibly because of its extensive use in termite control. As the pesticides interfere with $\mathrm{Ca}^{++}$metabolism and act as enzyme inhibitors also, their indiscriminate use poses great human health risk as evident from the present data. 


\begin{tabular}{|c|c|c|c|c|c|c|}
\hline \multirow{2}{*}{ Hospitals } & \multicolumn{6}{|c|}{ Pesticide residues $(\mu \mathrm{g} / \mathrm{g}$ Fat) } \\
\hline & DDT & DDE & Dieldrin & Aldrin & Deltamethrin & Malathion \\
\hline Jinnah ${ }^{19}$ & $\begin{array}{c}12^{*} \\
7-\mathrm{ND}\end{array}$ & $\begin{array}{c}2^{*} \\
17-N D\end{array}$ & $\begin{array}{c}4^{*} \\
15-N D\end{array}$ & $\begin{array}{c}2^{*} \\
\uparrow 31.000 \\
17-N D\end{array}$ & $\begin{array}{c}2^{*} \\
\uparrow 7.990 \\
\uparrow 6.290 \\
17-N D\end{array}$ & 19-ND \\
\hline Baqai 10 & 10-ND & $\begin{array}{c}1^{*} \\
9-\mathrm{ND}\end{array}$ & $10^{*}$ & 10-ND & 10-ND & 10-ND \\
\hline
\end{tabular}

Superscript number in hospital = Total no. of samples, ${ }^{*}$ number $=$ Number of detection, ND $=$ Not detected, $\uparrow=$ High value.

Table 9. Content of pesticide residues in Adipose tissue samples of Jinnah hospital.

\section{Residues in fish tissues}

Detection of pesticide residues DDT, DDE, aldrin, dieldrin and deltamethrin in fat, muscles and liver of three Labeo species of fish found in Kalri and Haleji lakes were also done by Saqib et al. (2005). In this study total 45 samples were taken and out of which 18 samples were found positive. The data indicates that DDT was found in small quantities while DDE was found higher in most of the samples. In few samples deltamethrin was also detected. This means slightly high level of residues were found in Kalri lake samples. However quantity of pesticides were higher in Haleji lake due to polluted nature of water while number of pesticides was more in Kalri lake water possibly due to the surrounding adjacent agricultural farms. It is then concluded that use of pesticides should be done with great

\begin{tabular}{|c|c|c|c|c|c|c|}
\hline \multirow{3}{*}{$\begin{array}{c}\text { Fish } \\
\text { Tissue } \\
\text { Sample }\end{array}$} & \multicolumn{3}{|c|}{ KALRI LAKE } & \multicolumn{3}{|c|}{ HALEJI LAKE } \\
\hline & \multicolumn{3}{|c|}{ Pesticide residues $(\mu \mathrm{g} / \mathrm{gm})$} & \multicolumn{3}{|c|}{ Pesticide residues $(\mu \mathrm{g} / \mathrm{gm})$} \\
\hline & L. rohita & L. calabasu & L. sindensis & L. rohita & $\begin{array}{c}\text { L. } \\
\text { calabasu }\end{array}$ & L. sindensis \\
\hline Fat 6 & $\begin{array}{c}\text { Deltamethrin } \\
0.35 \\
\text { DDT } \\
\text { (Traces) } \\
\text { DDE } \uparrow 11.3 \\
\text { Aldrin } 0.135\end{array}$ & $\begin{array}{c}\text { DDT } 0.40 \\
\operatorname{DDE} \uparrow 9.30\end{array}$ & $\begin{array}{c}\text { Deltamethrin } \\
2.2 \\
\text { DDT } 0.14 \\
\text { DDE } \uparrow 5.78\end{array}$ & $\begin{array}{c}\text { Dieldrin } \\
\uparrow 3.5 \\
\text { Aldrin } \\
0.15\end{array}$ & $\begin{array}{c}\text { DDT } \\
0.41 \\
\text { DDE } \\
\uparrow 142.2\end{array}$ & $\begin{array}{c}\text { DDT } 0.75 \\
\operatorname{DDE} \uparrow 11.0\end{array}$ \\
\hline$\underset{6}{\text { Muscles }}$ & $\begin{array}{c}\text { Deltamethrin } \\
0.40 \\
\text { DDE } 3.0 \\
\text { Aldrin } 0.46\end{array}$ & $\begin{array}{c}\text { Deltamethrin } \\
1.8\end{array}$ & $\begin{array}{c}\text { Deltamethrin } \\
1.66 \\
\text { DDT } 0.09 \\
\text { DDE } 3.3\end{array}$ & $\begin{array}{c}\text { DDE } 4.7 \\
\text { Aldrin } \\
0.56\end{array}$ & $\begin{array}{c}\text { DDT } \\
1.74 \\
\text { DDE } \\
\uparrow 70.67\end{array}$ & $\begin{array}{c}\text { DDT } 1.35 \\
\text { DDE } \uparrow 13.88 \\
\text { Dieldrin } 1.84\end{array}$ \\
\hline Liver 6 & \begin{tabular}{|c} 
Deltamethrin \\
1.7 \\
DDT \\
(Traces) \\
DDE 0.70 \\
Aldrin 0.03
\end{tabular} & Aldrin 0.31 & $\begin{array}{c}\text { Deltamethrin } \\
2.7\end{array}$ & $\begin{array}{c}\text { Not } \\
\text { detected }\end{array}$ & $\begin{array}{c}\text { DDT } \\
0.33 \\
\text { DDE } \\
\uparrow 15.83\end{array}$ & $\begin{array}{c}\text { Deltamethrin } \\
0.14\end{array}$ \\
\hline
\end{tabular}

Superscript number in hospital $=$ Total number of fish tissue samples, $\uparrow=$ High value

Table 10. Quantity of pesticide residues in different tissues of three fish species from Kalri and Haleji lakes. 
care, otherwise it will end up in hazardous effects as evident from the presence of pesticide residues in fishes in the present data. This is especially dangerous because Kalri lake water is being used as a source of water supply for Karachi population (16 millions).

\section{Pesticide degradation}

Degradation of pesticides is defined as the breakdown of toxic chemicals into nontoxic compounds and in some cases they return back into their original elements. The degradation or breakdown of pesticides can occur in plants, animals, soil and water. It can also occur upon exposure of ultra-violet radiation. The most common type of degradation that occurs is through the activity of microorganisms particularly the fungi and bacteria. According to the nature of degradation in the environment, the pesticides are grouped as persistent pesticides (i.e., DDT, aldrin, dieldrin and cadmium compounds) and nonpersistent pesticides (i.e., malathion, lindance, paraquat, mancozeb etc) were indentified.

We are presenting here the pathway of degradation of some of the pesticides e.g.
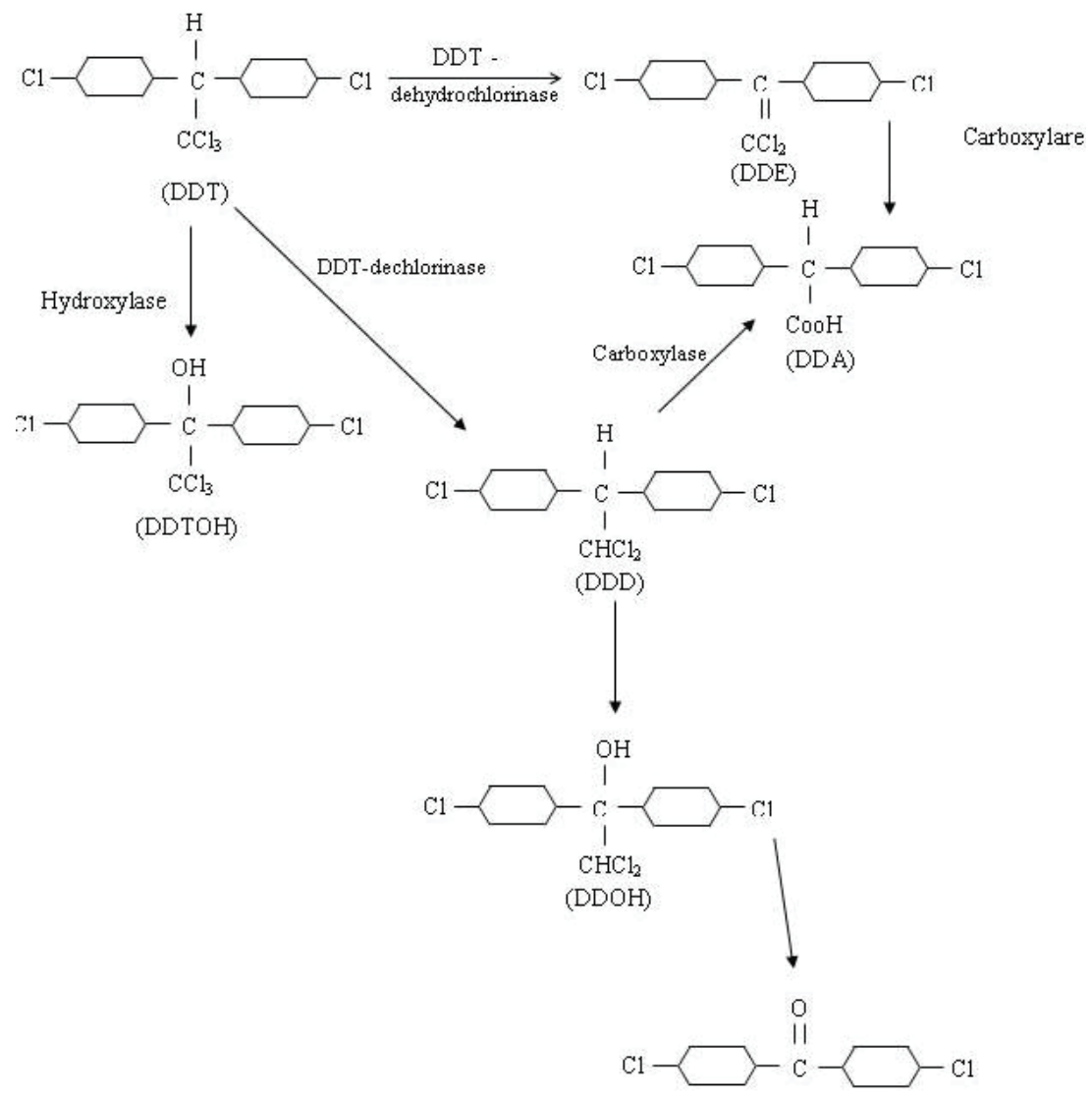

(Unknown conjugates)

Fig. 1. Degradation and metabolism of DDT 


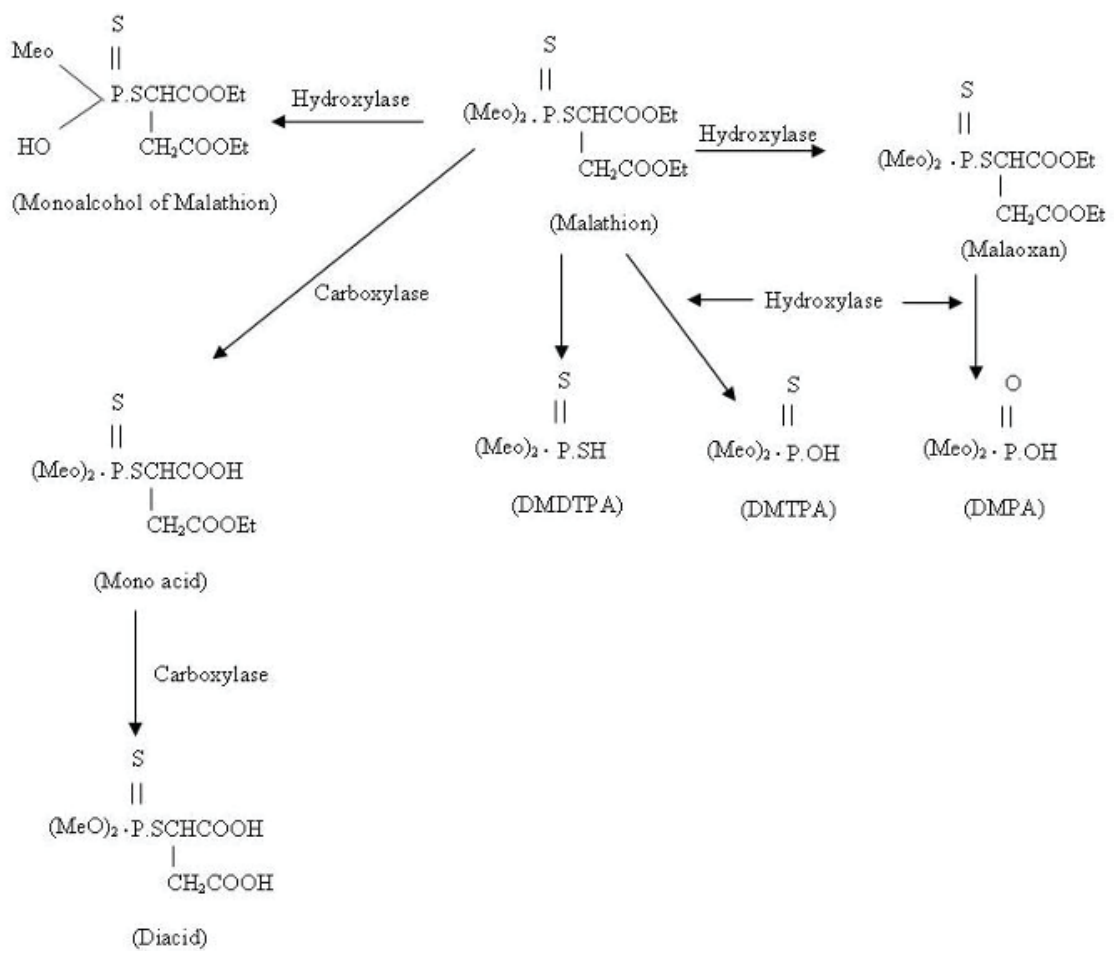

Fig. 2. Degradation and metabolism of Malathion

\section{B. Pesticide resistance:}

Today, possibly no one can ignore from the word "Pesticides" whether living in villages or in cities. This is due to the fact that everyone is exposed to pesticides directly or indirectly or comes in contact with them to a lesser or greater degree, in an attempt to kill our common enemy the "Pest" (generally insects) either in the field or at home. This struggle is going on since the man stepped on this earth. Various methods of controlling pests have been used by man from the very beginning. At present the use of conventional pesticides is the most common, economical and easiest method. However, there are certain problems associated with it like bioaccumulation, pollution, residues and resistance. In this section, we will briefly discuss the last one i.e., resistance.

Pesticide resistance is the adaptation of pest species targeted by a pesticide resulting in decreased susceptibility to that chemical. In other words, pests develop a resistance to a chemical through selection; after they are exposed to a pesticide for a prolonged period it no longer kills them as effectively. These factors increase the level of tolerance in the particular pest strain to a great limit. The phenomenon is biochemical and genetically. It may be determined by simple bioassay method or by determination of enzyme levels and marking of particular genes located on various chromosomes. Here we will not discuss the methods of determination of resistance but we will provide the information regarding the survey positions of resistance to pesticides in and outside of Pakistan. Hundreds of species and strains have been reported to be resistant to various pesticides or groups of pesticides. Sometimes cross resistance also develops. Only among mosquitoes 96 species have been 
reported resistant to one or more groups of pesticides as described by Georghiou and Mellon (1983). Among these 36 were resistant to one group, 32 to two groups, 18 to three groups, 8 to four groups and only one to all five groups of pesticides. One of the earliest report in this connection is that of Chattoraj and Brown (1960).

\section{Factors responsible for resistance}

As mentioned earlier resistance may develop due to the indiscriminate use or constant use or selection pressure but the factors identified in case of various groups are genetical as reported by Wood (1983). Resistance against organophosphates (OP) and Carbonates (CB) in case of mosquitoes has been reported due to increased level of detoxifying esterases (Georghious and Pasteur 1978, 1980; Wood et al. 1984; Wachendorf - Neumann 1984; Wang et al. 1984; Yasotomi, 1970). An increase in detoxifying phorsphomono-estereases was reported by Naqvi et al. (1969) as well. Hemigngway (1982) reported similar increase in the level of Carboxylesterase in a resistant strain. Resistance to pyrethroids in Aedes aegypti was reported by Chadwick et al. (1977). Higher resistance against permethrin was obtained by selection method and has been reported by Malcolm (1983). Due to this, attempts are being made to overcome this by using alternate methods or control or using mixture of pesticides with negative correlation of resistance or by rotating the pesticides. For this purpose computer stimulation technique and recombinant DNA technique is being tried now.

\section{Position in Pakistan}

Very little work on pesticide resistance is being done in Pakistan and that too only in health sector. Several studies have been conducted to support the resistant phenomenon against different pesticides. In this connection a study was carried out by Naqvi et al. (1987) for the resistance development in mosquitoes and houseflies in Karachi against DDT and malathion. In this study pesticides (DDT and malathion) were tested against different strains of mosquito species to determine the resistance phenomenon. The details are as under:

\begin{tabular}{|l|c|c|}
\hline \multicolumn{1}{|c|}{ Strain } & DDT $(\boldsymbol{\mu g})$ & Malathioin $(\boldsymbol{\mu g})$ \\
\hline $\begin{array}{l}\text { Musca domestica } \\
\text { DDT resistant strain } \\
\text { (PCSIR Strain) }\end{array}$ & 8.8 & 2.2 \\
$\begin{array}{l}\text { Musca domestica } \\
\text { (PCSIR Strain) }\end{array}$ & 2.0 & 2.4 \\
$\begin{array}{l}\text { Musca domestica } \\
\text { (Malir Strain) }\end{array}$ & 19.0 & 8.8 \\
$\begin{array}{l}\text { Aedes aegypti } \\
\text { (Susceptible London strain) }\end{array}$ & $0.020 \%$ & $0.8 \%$ \\
$\begin{array}{l}\text { Aedes aegypti } \\
\text { (PCSIR Strain) } \\
\begin{array}{l}\text { Culex pipiens } \\
\text { (Karachi University strain) }\end{array}\end{array}$ & $0.019 \%$ & $0.16 \%$ \\
\hline
\end{tabular}

Table 11. Comparison of $\mathrm{LC}_{50}$ of DDT and Malathion against various strains of mosquitoes and houseflies. 
Similar type of studies have been investigated by other researchers (Azmi et al. 1988, 1990, 1991; Naqvi and Tabassum 1992; Naqvi et al. 1993; Azmi et al. 1993; Rahila et al. 1993; Khan et al. 1993; Rahila et al. 1994; Azmi et al. 1995; Naqvi et al. 1995; Khan et al. 1996; Kahkashan and Naqvi, 1997; Naqvi et al. 1999; Kahkashan et al. 2001; Azmi et al. 2002).

Keeping in view excessive use of pesticides, the reports of Baig (1982), Khan et al. (1987), Naqvi et al. (1987) and Azmi et al. (2001) about increased resistance against certain organochlorine and organophosphate compounds in houseflies, vinegar flies and various species of mosquitoes have been reported that better alternative methods should be adopted to overcome the situation. Recently, the similar type of study has been conducted by Zafar et al. (2009) about the residual analysis of biopesticide by HPLC and resistance determination in different populations of Sitophilus oryzae against Biosal, Cypermethrin and Phosphine on the basis of enzyme activity. Thus, it may be concluded that neem fractions may successfully be used as pesticides, although the dose may be higher but not lethal. Availability of neem in Agro-Asian countries is more and this will help in developing a cheaper, safer and easier method to apply which will not produce the problem of resistance and pollution in comparison to imported conventional pesticides.

\section{Pesticidal hazards affecting health and environment:}

Pesticides when used properly are of tremendous benefits to human being, their indiscriminate use, however may cause considerable hazards to health and environment. Investigators feel that some workers did not report illness due to pesticide exposure; therefore, including un-reported cases the total numbers might be significantly higher Howitt and Moore (1975).

\section{Problems associated with the indiscriminate use or misuse of pesticides}

Among many problems, we have been facing in Pakistan is the problem of pollution, because convential pesticides are chemicals which act as poisons or toxic agents. So they pollute the atmosphere. By general spraying not only the target species but non-target animals and even human beings are affected. Therefore, there is a general tendency in the West towards the use of $4^{\text {th }}$ generation pesticides. A greater part of pesticides used for killing pests persist in the environment and may be accumulated in human body by many ways such as through drinking, water, vegetables and fruits etc. The meager quantity of such insecticides gradually increase in the body which become the cause of many human diseases like gastric cancer, cytogenetic damage, kidney infections and others (Anna et al. 1988; Sandra et al. 1992). Chlorinated, organophosphates and carbamates pesticides have also been reported in various human matrices (Saltatas and Gagliardi, 1990; Alwai et al. 1992; Ferrer et al. 1992; Saad et al. 1992).

\section{Pesticide poisoning:}

Pesticides are poison, and their acute exposure or continuous exposure result in several neurotic and pathological effects. Acute and severe exposure results in the inhibition of enzymes and physiological disorder. Continuous exposure results in malfunctioning of liver, kidney and heart. They are cytotoxic and damaging the cells and therefore these organs are affected. Certain pesticides e.g. ethyl selenac, mirex, penfluron are carcinogenic. Pesticide inhalation for a longer period affect the alveoli of lungs and so person develops into respiratory diseases. If tissues of the kidney is damaged then kidney function is affected. If the cholinesterase level is low continuously, it results in muscular twitching and 
trembling of arms and legs. Most of the pesticides are teratogenic at high dose. They also disturb the metabolism $(\mathrm{Ca}++, \mathrm{Mg}++)$. Cummulative effect of lipophilic pesticides may result in instantaneous death which is not detectable or diagnosable.

Different group of pesticides such as organchlorines have been correlated with dehydrogenases while organophosphates and carbamates have been correlated with cholinesterase, phosphomonoesterase, aliesterase, carboxylesterases, transaminases, monoxygenases, P-450 etc. Large number of publications is available in this respect. However, some recent reports are referred here e.g., Akgur et al. (1999) reported the effect of OP's on cholinesterase and paroxonase activities in human exposed persons. Husin et al. (1995) reported the effect of pesticide exposure on cholinesterase in farm workers. Krieger and Dim-off (2000) also reported the effect of malathion on cholinesterase in California date palm spray men. Regarding pesticidal effect on blood parameters scanty literature is available such as Dunstan et al. (1996) examined the effect of chtorinated hydrocarbons on various blood parameters in exposed persons.El-saeed and Hassan (2000) reported the relationship between chronic lymphocytic leukemia and pesticide exposure among Egyptian farm workers.

In Pakistan, Khan et al. (2000) reported the effect of pesticides in cotton field workers. Naqvi et al. (1970), Naqvi and Jahan (1999) and Rehman et al. (2002) reported the inhibition of acid and alkaline phosphatase in various cases. Khan et al. (2003) also investigated the inhibitory effect of pesticides in liver and kidney enzymes of Agama lizard. Similarly Azmi et al. (2006) examined the enzymatic activities of GOT, GPT and ALP in pesticide exposed farm workers of Gadap area, Karachi. During investigation they found that most of the workers showed elevated levels of enzymes except in few cases. This shows that these persons are highly exposed with pesticides during spraying time and their case history clearly indicate the degree of exposure due to which they get suffered with hepatitis, liver dysfunction and also complained about the clinical effects of liver. Similarly some workers who were exposed to cypermethrin, diazinon, monocrotophos simultaneously showed high level of of GOT and ALP. These persons due to the cumulative effect of these pesticides ultimately suffered with dyspnea, cyanosis, vomiting, backache and burning sensation in urine.

In another study which is carried out by Azmi et al. 2007 in the rural area of Gadap, Karachi almost all the persons showed higher level of cholinesterase except two persons that showed low level of cholinesterase probably due to the receptor binding by the molecule of pesticides or poisoning effect of pesticides used in these areas by the workers. Similar type of study is also carried out by Shahida et al. (2008) to observe the enzyme activities of GOT, GPT, ALP, cholinesterase and gamma-GT in the general population belonging to the different division of Sindh province, Pakistan.

Various blood components are also affected by the exposure of pesticides e.g., Bhalla and Agrawal (1998) reported the alteration in RBC membrane in rats by $\mathrm{HCH}$ exposure. Bailey and Jenkins (2000) reported the development of chronic leukemia in Egyptian farm workers. They also reported hight lymphocyte, WBC and platelet counts. The same findings have also been noticed by Azmi et al. (2009) in which 90\% of exposed farm workers had high lymphocyte count thus confirming the report of El-Saeed and Hassan (2000) about the relationship between chronic lymphocytic leukemia and pesticide exposure.

\section{Symptoms and treatment of pesticide poisoning}

Different group of pesticides produce characteristic adverse effects on human health and so alter the normal functioning of human life. 


\section{Organochlorines (OC)}

This group mainly affects the CNS which appears as headache, fever, and convulsion or muscular twitching, unconsciousness in extreme condition. Inhalation of carbogonium (5$10 \% \mathrm{CO}_{2}$ in $\mathrm{O}_{2}$ ), then give phenobarbital ( $\left.0.25-0.5 \mathrm{gm}\right)$. Injection of calcium gluconate may also be given. Restore dehydrochlorine activity.

\section{Organophosphate (OP)}

OP is inhibitors of cholinesterase and other enzymes like GOT, GPT and general esterases. Symptoms of poisoning are headache, giddiness, blurred vision, weakness, nausea, cramps, convulsions and discomfort in breathing. Immediately ChEase activity in blood serum should be checked (50-100\% activity normal $20-50 \%$ mild effect, $10-20 \%$, moderate effect and $0-10 \%$ severe effect). Artificial respiration should be given. Administer atropine sulphate 25 mg and repeat every 10 minutes till tachycardia as high as 120-140 per minute. Give 2-PAM 1 gram for adult and 0.25 gram for infant. Observe the patient for $24-48 \mathrm{hrs}$. (Do not give large amount of fluids by any route and in case of egamotic condition first restore respiration and then give atropine sulphate).

\section{Carbamates (CB) and Synthetic Pyrethroids(SP):}

They are also reversible cholinesterase - inhibitors. If used constantly produce different symptoms which are: salivation, constriction of pupil, profuse sweating, vomiting, pulmonary difficulty and muscular in coordination. Artificial respiration should be given and then administer atropine sulphate. Administration of 2-PAM and other oximes may not be useful and sometime harmful so it should be given under the advice of specialist or toxicologist.

This data which is a fragment of the whole literature on this topic is a significant proof of the hazardous effects of the over use and misuse of pesticides. We believe that this is a clear health risk to human health.

\section{Conclusion and recommendations:}

Being potentially dangerous and harmful to human health little attention was paid to the long-term impact of chemical pesticides on our environment as well as on the health hazards.

Poisoning due to the use of chemical pesticides sometimes do not readily show up. The signs of affected health become visible only after prolonged exposure to the poisons. Persistent insecticides such as DDT and other organochlorine insecticides which retain their toxicity even after a lapse of many years and pesticides which degrade into toxic residues are of great danger to human and animals. Several of the organophosphates (OP) and synthetic pyrethroids (SP), cause inhibition and elevation of cholinesterase due to the cumulative effect of pesticides and show the symptoms of neurotoxicity, hepato-toxicity, RTI and kidney dysfunctions etc.

There are two extremes if we see the policy of pest management in the west and our farmers. In west they have switched over to IPM and not only this but as a rule they have made it compulsory that atleast $50 \%$ agro-chemicals should be phytopesticides, where as in Pakistan the farmers want to use only synthetic, highly toxic pesticides and that too they will spray without proper clothing, gloves, googles and masks, on the pretext that the weather is too hot. We know that our farmers hesitate in using phytopesticides, because their effects can be observed after 72 hours and not in few minutes as seen in case of 


\begin{tabular}{|c|c|c|}
\hline Groups & Pesticides & Antidotes \\
\hline $\begin{array}{l}\text { Group-I } \\
\text { Organophosphates }\end{array}$ & $\begin{array}{l}\text { Azodrin, trithiion, dasanit, } \\
\text { DDVP, demeton, } \\
\text { dimethoate, durstban, } \\
\text { ethion, fncthion, metasytox, } \\
\text { methyl parathion, monitor, } \\
\text { phorate \& phosphamidon, }\end{array}$ & $\begin{array}{l}\text { Atropine Sulphate is used. } \\
\text { Injections should be repeated as } \\
\text { symptoms recure. } \\
\text { Prontopam chloride (2-PM) } \\
\text { should be injected intravenously. }\end{array}$ \\
\hline $\begin{array}{l}\text { Group-II } \\
\text { Carbamates }\end{array}$ & $\begin{array}{l}\text { Aldicarb, Carbofuran, } \\
\text { Propoac, Methomyl \& } \\
\text { Carbaryl. }\end{array}$ & $\begin{array}{l}\text { - } \begin{array}{l}\text { Artophine sulphate. } \\
\text { Protopam chloride (2-PM) must } \\
\text { not be used. }\end{array} \\
\end{array}$ \\
\hline $\begin{array}{l}\text { Group-III } \\
\text { Chlorinated }\end{array}$ & $\begin{array}{l}\text { Endrin, dieldrin, aldrin, } \\
\text { Lindane, endosulfan, BHC, } \\
\text { DDT \& toxaphane }\end{array}$ & $\begin{array}{l}\text { Barbiturates for convulsions or } \\
\text { restlessness } \\
\text { Calcium gulconate given } \\
\text { intravenously. } \\
\text { Epinephrine (adrenalin) should } \\
\text { not be used. }\end{array}$ \\
\hline $\begin{array}{l}\text { Group-IV: } \\
\text { Inorganic arsenicals }\end{array}$ & $\begin{array}{l}\text { Sodium arsenite \& Paris } \\
\text { green. }\end{array}$ & $\begin{array}{l}\text { BAL (dimereaprol) is specific for } \\
\text { arsenic poisoning, intramuscular } \\
\text { injection. }\end{array}$ \\
\hline $\begin{array}{l}\text { Group-V: } \\
\text { Cyanides }\end{array}$ & $\mathrm{HCN}$ or Cyanogas & $\begin{array}{l}\text { - } \\
\text { - } \\
\text { intravium nitrite through inhalation. } \\
\text { intraven } \\
\text { Sodium thiosulphate given } \\
\text { intravenously. }\end{array}$ \\
\hline $\begin{array}{l}\text { Group-VI: } \\
\text { Anticoagulants }\end{array}$ & $\begin{array}{l}\text { Warfarin, Valene, Pival \& } \\
\text { Dephacin }\end{array}$ & $\begin{array}{l}\text { - Vitamin K by mouth, } \\
\text { intravenously or intramuscularly. } \\
\text { - Vitamin C is useful adjunct. }\end{array}$ \\
\hline $\begin{array}{l}\text { Group-VII: } \\
\text { Fluoracetates }\end{array}$ & Sodium fluroacetate & $\begin{array}{l}\text { - Monacetin (Glyceral monacetate) } \\
\text { intramuscularly. }\end{array}$ \\
\hline $\begin{array}{l}\text { Group-VIII } \\
\text { Dinitrophenols }\end{array}$ & DNOC \& Dinoseb & $\begin{array}{l}\text { - Atropine sulphate must not be } \\
\text { used } \\
\text { Life support should be } \\
\text { maintained. } \\
\text { - Sodium methyl thiouracil may be } \\
\text { used to reduce basal metabolic } \\
\text { rate. }\end{array}$ \\
\hline $\begin{array}{l}\text { Group-IX: } \\
\text { Bromides }\end{array}$ & $\begin{array}{l}\text { FDB \& MB or mixture of } \\
\text { EDB+MB }\end{array}$ & $\begin{array}{l}\text { BAL (dimercaprol) may be given } \\
\text { before symptoms appear. } \\
\text { - } \quad \text { Barbiturates for convulsions. }\end{array}$ \\
\hline $\begin{array}{l}\text { Group-X: } \\
\text { Chlorophenoxy } \\
\text { Herbicides, Urea }\end{array}$ & $\begin{array}{l}\text { 2-4-D, 2,4,5-T } \\
\text { Momiron, Diuron, Bromacil, } \\
\text { Paraquat \& Diaquat. }\end{array}$ & $\begin{array}{l}\text { - } \quad \text { None available. } \\
\text { Life support should be } \\
\text { maintained. }\end{array}$ \\
\hline
\end{tabular}

Table 12. Antidotes for pesticide positioning 
conventional pesticides. So, one should think that is it not better to get slightly lesser kill of pests in the long run and using a safe method of control, so that your health and health of your family as well as your animals are saved". We wish to end this manuscript with the following phrase:

\section{"Pesticides are double edged sword, if used intelligently will kill the enemy - and if carelessly will kill you". \\ THEREFORE, BETTER TO ADOPT SAFETY MEASURES TO SAVE YOUR HEALTH AND ENVIRONMENT FROM POLLUTION.}

\section{References}

Abu-Qare, A.W. \& Abu-Donia, M.B.,(2001-a). Determination of diazinon, chlorpyrifos and their metabolites in rat plasma and urine by high performance liquid chromatography. J. Chromatogr. 39: 200 - 204.

Abu-Qare, A.W. \& Abu-Donia, M.B., (2001-b). Performance of liquid chromatographic determination of diazinon, permethrin. DEET (N, N-diethyl-m-toluamide), and their metabolites in rat plasma and urine. J. Anal. Chem. 370: 403 - 407.

Ahmed, M.T., Loutfy. N. \& El-Sheikh, E. (2002). Residue level of DDE and PCB's in the blood serum of women in the Port Said region of Egypt. J. Hazard. Mater. 89: 41 -48.

Akgur, S.A., Ozturk, P., sozimen, E.Y., Delen, Y., Tanyalcin, T. \& Ege, B. (1999). Paraoxonase and achtylcholinesterase activities in human exposed to organophosphorus compounds. J. Toxicol. Environ. Health A. 58: 469 -474.

Alawai, M.A., Ammari, N. \& Yousuf. A.S. (1992). Organochlorine pesticide contamination in human with samples from women living in Amman, Jordan. Toxicol. 23: 235 - 239.

Anna, P., Nandoor, P. \& IIdiko, F.(1988). Pesticide use related to cancer incidence as studied in a rural district of hungary. Sci. Total. Environ. 73: 229 - 244.

Azmi, M.A. Naqvi, S.N.H., Akhtar, K. \& Ahmad, I. (1988). Determination of cholinesterase in standard and wild culicine mosquito larvae of Karachi region after treatment with DDT and Malathion. Pak. J. Ent. 9: 115 - 124.

Azmi, M.A., Naqvi, S.N.H. \& Akhtar, K. (1990). Determination of esterases in DDT susceptible and resistant strains of culicine mosquitoes. J. Sci. Kar. Univ. 18: 137 151.

Azmi, M.A., Naqvi, S.N.H. \& Akhtar, K. (1991). Determination of resistance in culicine mosquitoe larvae of Karachi by WHO method. J. Sci. Kar. Univ. 19: 139 - 144.

Azmi, M.A., Naqvi, S.N.H. \& Akhtar, K. (1993). Comparative study of toxicity of DDT and Malathion and solfac against various strains of Culex Fatigans by WHO method. Proc. Pak. Congr. Zool., 13, pp. 359 - 366.

Azmi, M.A., Naqvi, S.N.H. \& Akhtar, K. (1995). Correlation of resistance with phosphomonoesterases in susceptible and resistant strains of mosquitoes. Pak. J. Entomol. 10: 19 -24.

Azmi, M.A., Naqvi, S.N.H. \& Akhtar, K., Ahmed, I., Rizvi, S.A. \& Rais, S. (2001). Determination of toxicity of DDVP and cypermethrin on Collosbruchus analis. F and 
their effect on alkaline phosphatase and choinesterace activity. Proc. Pak. Congr. Zool. 21: 289 -293.

Azmi, M.A., Ahmed, I., Naqvi, S.N.H. \& Akhtar, K. (2002). Level of lactate dehydrogenase (LDH) in resistant and surceptible strains of culicine mosquitoes of the Karachi region after treatment with DDT, malathion and cyfluthrin. Turk. J. Zool. 26: 97 100.

Azmi, M.A., Naqvi, S.N.H., Azmi, M.A. Jr. \& Aslam, M. (2006). Effect of pesticide residues on health and different enzyme levels in the blood of farm worker from Gadap (rural area) Karachi-Pakistan. Chemosphere. 64: 1739 - 1744.

Azmi, M.A., Naqvi S.N.H., Moinuddin., Azmi, M.A. Jr., Aslam, M. \& Rehana, P. (2007). Effect of pesticide residues on health and enzymes in the blood of farm workers around Karachi-Pakistan J. Exp. Zool. India. 10: 43 - 54.

Azmi M.A., Naqvi S.N.H., Kehkashan, A., Moinuddin., Shahida, P., Rehana, P. \& Aslam, M. (2009). Effect of pesticide residues on health and blood parameters of farm workers from rural Gadap, Karachi-Pakistan. J. Environ. Biol. Ind. 30: 747 - 756.

Baig, M.M.H. (1982). Resistance of pesticide use in public health in Pakistan. FAO International workshop on resistance. Srilanka.

Bailely, B.J. \& Jenkins, J.J. (2000). Association of azinphos - menthyl with rat erythrocytes and hemoglobin. Arch. Toxicol. 74: 322 - 328.

Bhalla, P. \& Agarwal, D. (1988). Alterations in rat erythrocyte membrane due to hexachlorocycle-hexane (technical) exposure. Hum. Expt. Toxicol. 17: 638 -642.

Bissacot, D.Z. \& Vassilieff, I. (1997-b). HPLC determination of flumethrin, deltamethrin, cypermethrin and cyhalothrin residues in the milk and blood of lactating dairy cows. J. Anal. Toxicol. 21: 397 - 402.

Butler, W.J., Saddon, L., McMullen, E., Houseman, J., Tofflemire, K., Corriveau, A., Weber, J.P., Mills, C., Smith, S. \& Van Oastdam, J. (2003). Organochlorine levels in maternal and umbilical cord blood plasma in Arctic Canada. Sci. Total. Environ. 2: 27 - 52.

Cantor, K.P., Blair, A., Everett, G., Gilsor, R., Brumeister, L.F., Brown, L.M. et al.(1992). Pesticides and other agricultural risk factors for non - Hodgkin's lymphoma among men in Jowa and Minnesota. Cancel Res. 52: 2447 - 2455.

Casarette, J.J., Freyer, G.C., Yauger, W.L. \& Klemner, H.W. (1968). Organochlorine pesticides residues in human tissue. Hawaii Arch. Environ, Health. 17: 306 - 311.

Chadwick, P.R., Invest, F.J. \& Brown, M.J. 1977. Pyrethroid reistance in Aedes aegypti in a Bangkok population Pestic. Sci. 8: 618 -624.

Chattraj, A.W. \& Brown, A.W.A. (1960). Internal DDE production by normal and DDT resistant larvae of Aedes aegypti. J. Econ, Ent. 53: 443 - 455.

Chikuni, O., Skare, U., Nyazema, N. \& Poider, A. (1991). Residues of organochlorine pesticides in human milk from mothers living in greater Harare area of Zimbabwe. Cent. Afr. J. Med. 37: $136-141$.

Cohen, J.A. \& Oosterbaan, R.A. (1963). The active site of acetylcholinesterase and related esterases and its reactivity towards substrates and inhibitor Springer-Verlag, Berlin.

Desola, S.R., Bisshop, C.A., Van der Kiraak, G.J. \& Brook, R.J. (1998). Impact of organochlorine contamination on levels of Dex hormones and external morphology of common snapping turtle in Ontario, Canada. Environ. Health. Perspect. 106: 253 260. 
Dua, V.K., Pant, C.S. \& Sharma, V.P. (1996). Determination of levels of HCH and DDT in soil, water and whole blood from bioenvironmental and insecticide-sprayed areas of malaria control. Indian. J. Malariol. 33: 7 - 15.

Dunstan, R.H., Roberts, T.K., Donohoe, M., McGregor, N.R., Hope, D., Taylor, W.G., Watkin, J.A., Murdoch, R.N. \& Butt, H.L. (1996). Bioaccumulated chlorinated lydrocarbons and red / white blood cell parameters. Biochem. Mol. Med. 58: 77 - 84.

El-Saeed, W.Y. \& Hassan, M.H. (2000). Chronic lymphocytic leukemia in Egyptian farm workers exposed to pesticides. East Mediterr. Health. J. 5: 960 - 966.

Ferrer, A., Bona, A.M. Castellano, M., ToFigueras, J. \& Brunet, M. (1992). Organochlorine residues in human adipose tissue of the population of Zaragoza (Spain). Bull. Environ. Centam. 48: 561-566.

Georghiou, G.P. \& Pasteur, N. (1978). Electrophoretic esterase pattern in insecticide resistant and susceptible mosquitoes. J. Econ. Ent. 71: 201 - 205.

Georghiou, G.P. \& Mellon, R.B. (1983). Pest resistance to pesticides. Edited by G.P. Georghiou and P. Siato. pp. 1 - 66 and $769-792$.

Guardino, X., Serra, C., Obiols, J., Rosell, M.G., Berenguer, M., Lopes, F. \& Porossa, J. (1996). Determinotion of DDT and related compounds in blood samples from agricultural workers. J. Chromatogr. A. 719: 141 -147.

Heath, D.F. (1961). Organophosphorus poisons. Pargamon Press. Oxford.

Hemingway, J. (1982). The biochemical nature of malathiion resistance in An. Stephensi. Pestic. Biochem. Physiol. 17: 149 - 155.

Heudorf, U., Angerer, J. \& Drexler, H. (2003). Current internal exposure to pesticide in children and adolescents in Germany: blood plasma levels of pentachlorophenol $(\mathrm{PCP})$, lindane (gamma - $\mathrm{HCH}$ ) and dichlorodiphenylethylene (DDE), a biostable metabolite of dichlorodiphenyl trichloroethane (DDT). Int. J. Hyg. Environ Health. 206: 1816 -1820.

Howitt, R.E. \& Moore, C.V. (1975). Pesticide injury reporting: One study; Econ. Social Issue, Univ. Claif. Cooperative Extension, Davis, CA. 05616.

Husin, L.S., Ultaman, A., Hisham, H.J., Hussain, I.H \& Jamil, M.R. (1999). The effect of pesticide on the activity of serum choloinesterase and current perception threshold on the paddy farmers in the Muda agricultural development area, Mada, Kedah, Malaysia. Med. J. Malaysia. 54: 320 - 324.

Jahan, M. (1995). Pesticide residues in random blood samples of human population in Karachi. JCPSF. 6: 151 - 153.

Jarrer, J., Goomen, A., Foster, W., Brant, R., Cham, S. \& Sevcik, M. (1998). Evaluation of reproductive outcomes in women inadvertently exposed to hexachlorobenzene in southern Turkey in 1980's. Reprod. Toxicol. 12: 469 -476.

Kahkashan, A. \& Naqvi, S.N.H. (1997). Effect of DDT and malathion on macromolecules (proteins) of susceptible and resistant strains of Musca domestica L. Pak. J. Entomol. 12: $37-42$.

Kahkashan, A. \& Naqvi, S.N.H., Ahmad, I. \& Azmi, M.A. (2001). Effect of resistance on the activity of acid and alkaline phosphatases after treatment with DDT and malathion in three different strains of Musea domestica L. Bulletin. Pure. Applied Sci. 20: 41 -50.

Kanja, L.W., Skaare, J.U., Ojwang, S.B. \& Maitai, C.K. (1992). A comparison of organochlorine pesticide residues in maternal adipose tissues, maternal blood, cord 
blood and human milk from mother / infant pairs. Arch. Environ. Contam. Toxicol. 22: $21-24$.

Khan, M.F., Rehana, A. \& Baig, M.M.H. (1987). Determination of resistance in local Drosophila against DDT in comparison with four different strains of Drosophila melanogaster. Pak. J. entomol. Kar. 2: 109 -120.

Khan, M.F., Rehana, A. \& Naqvi, S.N.H. (1993). Detection of DDT resistance level in Drosophila melanogaster of Karachi East region. Zoologica. Pak. 3: 57 - 60.

Khan, M.F., Naqvi, S.N.H., Azmi, M.A., Khan, M.I. \& Qadri, S.S. (1996). DDT reswidues on apple after spray for codling moth control. Pak. J. Entomol. Kar. 11: 21 -22.

Khan, M.F., Khan, M.I., Aslam, M. \& Naqvi, S.N.H. (2000). Study of cholinesterase level in blood of cotton field workers exposed to pesticides. J. Baqai. Med. Univ. 3: 12 -16.

Khan, M.Z., Naqvi, S.N.H., Khan, M.F., Tabassum, R., Ahmad, I., Farina, F. \& Tariq, R.M. (2003). Determination of induced effect of biosal (Neem-based formulation) on cholinesterase and protein in kidney and liver of Calotes versicolor Damdin. J. Exp. zool. India. 6: 175 -179.

Kocan, A., Petrik, J., Drobna, B. \& Chovancova, J. (1994). Levels of PCB's and some organochlorine pesticides in human population of selected areas of Slovak Republic. I. Blood. Chemosphere. 29: 2315-2325.

Krawinkel, M.B., Plehn, G., Kruse, H. \& Kasi, A.M. (1989). Organochlorine residues in Baluchistan / Pakistan: blood and fat concentration in human. Bull. Environ. Contam. Toxicol. 43: $821-826$.

Krieger, R.I. \& Dinoff, T.M.N. (2000). Malathion deposition, metabolite clearance and cholinesterase status of date dusters and harvesters in California. Arch. Environ. Contam. Toxicol. 38: 546 - 553.

Krauthacker, B., Tanja, A.K., Kralj, M, Thalcevic, B. \& Reiner, E. (1980). Organochlorine pesticides in blood serum of the general population of Yoguslavia and in occupationally exposed workers. Nt. Arch. Occup. Environ. Health. 45: 217 - 220.

Kusevitsky, I.A., Kirlich, A.Y \& Khovayera, L.A. (1970). Inhibitory effect of organochlorines on thyroid gland. Veterinanariya. 4: 73 - 77.

Luo, X.W., Foo, S.C. \& Ong, H.Y. (1997). Serum DDT and DDE levels in Singapore general population. Sci. Total. Environ. 208: 97 - 104.

Malcolm, C.A. (1983). The genertic basis of pyrethrioid and DDT resistance interrelationship in Aedes aegypti. Genetica. 60: 213 -219.

Matsumura, F. \& Hogendijk, C.J. (1984). The enzymatic degradation of malathion in organophosphate resistant and susceptible strain of Musca domestica. Ento. Exp. Appl. 7: $179-193$.

Matuo, Y.K., Lopes, J.N.C., Carsanova, I.C., Matuo, T. \& Lopes, J.L.C. (1992). Organochlorine pesticide residues in human milk in the Ribeuao Preto region. State of Sao Pauto, Brazil. Arch. Environ. Contam. Toxicol. 22: 167 - 175.

Mercedes, B. \& Thiel, R. (1986). DDT and polychlorinated biphenyl residues in human milk. Rev. Costrarric Cienc. Med. 7: 1333 -136.

Mughal, H.M. \& Rahman, M.A. (1973). Organochlorine pesticide content of human adipose tissue in Karachi. Arch. Environ. Health. 27: 396 - 398.

Musshoff, F., Junker, H. Madea, B. (2002). Simple determination of 22 organophosphorus pesticides in human blood using head space solid - phase micro extraction and gas chromatography with mars spectrometric detection. J.Chromatogr. Sci. 40: 29 -34. 
Naqvi, S.N.H., Muzaffar, S.A. \& Ashrafi, S.H. (1970). Detoxification of DDT and its relation with inhibition of phosphomonesterase in desert laust, Schistocerca gregaria (Forskal). Pglanzenk. Pflanzenschutz. 77: 578 -581.

Naqvi, S.N.H. \& Tabassum, R. (1992). Probable development of resistance against neem extract (RB-A) and cyfluthrin (solfac 10\% E.C.) in Musca domestica L. (PCSIR Strain). Pak. J. Entomol. Kar.7: 9 -16.

Naqvi, S.N.H., Kahkashan, A. Azmi, M.A. (1993). Determination of toxicity and resistance in different strains of Musca domestica L. against DDT and malathion. Pak. J. Entomol. Kar. 8: 27 - 34.

Naqvi, S.N.H., Jahan, M., Tabassum, R., Qamar. S. J. \& Ahmad, I. (1995). Toxicity and teratogeny caused by coopex $25 \mathrm{EC}$ and a neem extract (n-7) against $3^{\text {rd }}$ instar larvae of Musca domestica L. Pak. J. Entomol. Kar. 27: 27 -31.

Naqvi, S.N.H. \& Jahan, M. (1995). Pesticide residues in random blood samples of human population in Karachi. JCPSF. 6: 151 - 153.

Naqvi, S.N.H. \& Jahan, M. (1996). Detection of some pesticides in blood of some people of Karachi by HPLC. JCPSP. 6: 151 - 153.

Naqvi, S.N.H. \& Jahan, M. (1999). Pesticide residues in serum and blood samples of the people of Karachi. J. Environ. Biol. 20: 241 - 244.

Ntow, W.J. (2001). Organochlorine pesticides in water, sediment, crops and human fluids in a farming community in China. Arch. Environ. Contam. Toxicol. 40: 557 - 563.

O' Brien, R.D. (1967). Insecticides, Action and Metabolism,. Academic press. Inc., Newyork.

O' Brien, R.D. (1976). Acctylcholinesterase and its inhibition. In wikinson, C.F. (ed): Insecticides, Biochemistry and Physiology. Plenum Press., Newyork. pp. 271 - 296.

Padungtod, C., Lasley, B.G.L., Christiani, D.C., Raayan, L.M. \& Xu, X. (1998). Reproductive hormone profile among pesticide factory workers. J. Occup. Environ. Med. 40: 1038 $-1047$.

Rubin, C.H., Lanier, A., Socha, M., Brock, J.W., Kieszak, S. \& Zahm, S. (2001). Exposure to presistant organochlorines among Alaska Native women. Int. J. Circumpolar. Health. 60: 157 - 169.

Rahila, T., Naqvi, S.N.H., Masarrat, J. \& Shaista, R. (1993). Determination of DDT and malathion resistance in $4^{\text {th }}$ instar larvae of Culex fahigans collected from NIPA and Urdu College Strations. Pak, J. Entomol. Kar. 8: 71 -78.

Rahila, T., Naqvi, S.N.H., Shaista, R., Masarrat, J. \& Khan, M.F. (1994). Susceptibility of different populations of Musca domestica against malathion and DDT in Karachi region. Zoologica. Pak. 4: $43-50$.

Rahman, M.F., Siddiqui, M.K. \& Jamil, K. (2002). Acid and alkaline phosphatase activities in a novel phosphorothionate (RPR - 11) treated male and female rats. Evidence of dose and time - dependent response. Drug. Chem. Toxicol. 23: 497 -509.

Saad, J.J., Robert, L.P. \& Alphonse, P. (1992). Measurement of DDT and DDE from serum fat and stool specimens. J. Environ. Health. 27: 967 - 981.

Sabbah, S., Jemaa, Z. \& Bouguerra, M.L. (1987). Gas chromatography study of organochlorine pesticide residues in human milk and umbilical cord and adult blood. Analysis. 15: 399 - 403.

Saddy, J.J., Robert, L.F. \& Alphouse, P. (1992). Measurement of DDT and DDE from Serum, fat and stool specimens. J. Environ. Sci. Health Part A, Environ. Sci. Eng. 27: 967 - 981. 
Saqib, T.A., Naqvi, S.N.H., Siddiqui, P.A. \& Azmi, M.A. (2005). Detection of pesticide residues in muscles, fat and liver of three species of Labeo found in Karli and Haleji lakes. J. Environ. Biol. 26: 4333 - 438.

Sandra., G.A., Norma, N.A., Austin, O., Fernando, G., Sergio, L. \& Rafael, V.P. (1992). Sisterchromatid exchange analysis in a rural population of Mexico exposed to pesticides. Mutat. Res. 281: 173 - 179.

Saltatos, L.G. \& Gagliardi, C.L. (1990). Desulfuration of the insecticide parathion by human placenta in vitro. Biochem. Pharmacol. 39: 799 - 801.

Saxena, M.C., Seth, T.D. \& Mahajan, P.L. (1980). Organochlorine pesticides in human placemta and accompanying fluids. Int. J. Environ. Anal. Chem. 7: 245 - 251.

Shahida, P. (2008). Determination of pesticide residues in blood samples from patients in rural Sindh and their effects on biochemical and hematological levels. Ph.D. Thesis.

Swaen, G.M.H., Varvliet, C., Slangen; J. J. M. \& Sturmans, F. (1992). Cancer mortality among licensed pesticide applicators. Scand. J. Work Environ. 18: 201 - 204.

Van Oastdam, J.C. Dewaitly, E., Gilman, J.C., Hamsen, J.O., Odland, V., Chaschchin, J. et al. (2004). Circumpolar maternal blood contaminant survey, 1994 - 1997 organochlorine compounds. Sci. Total. Environ. 330: 55 - 70.

Vilar, O. \& Tullner, W.W. (1959). Effect of DDT on sex hormones. Endocrinology. 65: 80 - 84.

Wachendoorf - Neumann, U. (1984). Diagnosis of insecticide resistance in aphids. Proc. XVII. Int. Cong. Entomol. Hamburg. 17: 1 -3.

Wakeling, A.E., Schmidt, T.J. \& visek, W.J. (1972). Inhibition of 5-dihydrotestosterone binding with specific protein receptors by dieldrin treatment. Fed. Proc. 31: 725.

Waliszewski, S.M., Aquirre, A.A., Infanzon, R.N., Silva, C.S. \& Silico, J. (2001). Organochlorine pesticide levels in maternal adipose tissue, maternal blood serum, unbilical blood serum and milk form inhabitants of Veravwz, Mexico. Arch. Environ. Contam. Toxicol. 40: 432 - 438.

Wang T.C., Feng. H.T. \& You, B.Y. (1984). Malathion resistance of peach aphid in Taiwan. Proc. XVII. Int. Cong. Entomol. Hamburg. 17: 1 - 2.

WHO, (1962). Toxic hazards of pesticides to man. Twelfth report of the Expert Committee on insecticides. Wld. Hlth. Org. Tech. Rept. Ser. No. 227.

Wood, R.J. (1983). Genetics. New Frontiers. Proc. XV. Int. Cong. Genetics. 125 -135.

Wood, R.J., Pasteur, N. \& Singere G. (1984). Carbamate and organophosphate resistance in Culex pipiens L. (Diptera Culicidae) in France and significance of Est-3-A. Bull. Ent. Res. 74: 677 - 687.

Yastomi, K. (1970). Studies on organophosphate resistance and esterase activity in mosquitoes of C. Pipiens group. Jap. J. Sanit, Zool. 21: $41-45$.

You, I., Casonova, m., Archibeque-Engle, S., Sar, M., Fam, I.Q. \& Heck, H.A. (1998). Impaired male sex development in prenatal spargue Dawley and long Evans hooded rats, exposed to utero and loctationally functional samples to $\mathrm{P}^{\prime} \mathrm{P}^{\prime}$ DDE. Toxicol. Sci. 45: 162 - 173.

Zafar, S.M.N. (2009). Determination of possible resistance in different populations of Sitophilus oryzae against biosol, cypermethrin and phosphine on the basis of enzyme activity. Ph.D. Thesis Part-A. 


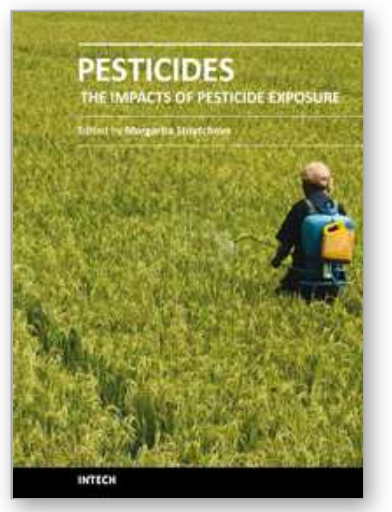

\author{
Pesticides - The Impacts of Pesticides Exposure \\ Edited by Prof. Margarita Stoytcheva
}

ISBN 978-953-307-531-0

Hard cover, 446 pages

Publisher InTech

Published online 21, January, 2011

Published in print edition January, 2011

Pesticides are supposed to complete their intended function without â€œany unreasonable risk to man or the environmentâ€. Pesticides approval and registration are performed â€œtaking into account the economic, social and environmental costs and benefits of the use of any pesticideâ€. The present book documents the various adverse impacts of pesticides usage: pollution, dietary intake and health effects such as birth defects, neurological disorders, cancer and hormone disruption. Risk assessment methods and the involvement of molecular modeling to the knowledge of pesticides are highlighted, too. The volume summarizes the expertise of leading specialists from all over the world.

\title{
How to reference
}

In order to correctly reference this scholarly work, feel free to copy and paste the following:

M. Ahmed Azmi and S.N.H. Naqvi (2011). Pesticide Pollution, Resistance and Health Hazards, Pesticides - The Impacts of Pesticides Exposure, Prof. Margarita Stoytcheva (Ed.), ISBN: 978-953-307-531-0, InTech, Available from: http://www.intechopen.com/books/pesticides-the-impacts-of-pesticides-exposure/pesticide-pollutionresistance-and-health-hazards

\section{INTECH}

open science | open minds

\section{InTech Europe}

University Campus STeP Ri

Slavka Krautzeka 83/A

51000 Rijeka, Croatia

Phone: +385 (51) 770447

Fax: +385 (51) 686166

www.intechopen.com

\section{InTech China}

Unit 405, Office Block, Hotel Equatorial Shanghai

No.65, Yan An Road (West), Shanghai, 200040, China 中国上海市延安西路65号上海国际贵都大饭店办公楼 405 单元

Phone: $+86-21-62489820$

Fax: $+86-21-62489821$ 
(C) 2011 The Author(s). Licensee IntechOpen. This chapter is distributed under the terms of the Creative Commons Attribution-NonCommercialShareAlike-3.0 License, which permits use, distribution and reproduction for non-commercial purposes, provided the original is properly cited and derivative works building on this content are distributed under the same license. 